\title{
Internship recommendation system using simple additive weighting
}

\author{
Priyo Aji Santoso ${ }^{1, *}$, Aji Prasetya Wibawa ${ }^{2}$, Utomo Pujianto ${ }^{3}$ \\ Department Of Electrical Engineering, State University Of Malang, Malang, Indonesia \\ ${ }^{1}$ priyoo.as@gmail.com *; ${ }^{2}$ aji.prasetya.ft@um.ac.id ${ }^{3}$ utomo.pujianto.ft@um.ac.id \\ * corresponding author
}

\begin{abstract}
ARTICLE INFO ABSTRACT
Article history

Received January 2, 2018

Revised January 21, 2018

Accepted February 7, 2018

Keywords

Recommendation system

Internship practice

Technology Acceptance Model

Internship is an activity that is compulsory for students of Vocational High School. Great selection of internships and the lack of information about the industry, is the common barriers of apprentice implementation. So find apprenticeship places that fit the needs of students to increase the intensity of the work and the motivation of students is not easy. Apprenticeship recommendation system using a simple additive weighting (SAW) can be used as a solution to assist students in determining the place of internship according to the needs of student. Method SAW can provide recommendations based on the weight of the priority criteria for students and can provide the level of accuracy of calculation of $100 \%$. Evaluation on the behavior of users of the system are also carried out, as many of the implementation of the system failed is caused not due to technical factors but more on users. The results of the evaluation of the Technology Acceptance Model (TAM) approach, the average of user already feel usability and ease of use. While the influence of TAM each variable can give significant effects.
\end{abstract}

This is an open access article under the CC-BY-SA license.

\section{Introduction}

Work-based learning, such as the internship program has become an increasingly popular way to help students build skills and gain exposure to real world for a career in the field of their interest [1], [2]. Apprenticeship is an activity compulsory for vocational high school students. Learning in the corporate world or the world industry is apprenticeship that practice for implementation of learning activities, consolidate, and improve the competence of students. The implementation of the internship involves experienced practitioners through expert supervision practice [3].

The selection of the place of internship that suits the needs of the students is very important to increase the intensity of work and motivation of working students. Bad internship experience can easily change the behaviour of the people to keep away from the industrialized world [4]. Apprenticeship programs that failed to meet the expectations of students will make them reluctant to work with a maximum in the execution of the internship [5].

Given the importance of selecting the appropriate apprenticeship places, computerized technology is needed that is able to deliver apprenticeship places so that recommendations could be made a referral to the students although it is not mandatory. Computerized technology that can handle the problem is a software model of a decision support system (DSS). The DSS is an interactive computerbased systems that can help decision makers in determining options [6]-[8].

The DSS uses the SAW method. Some examples of problems using methods including SAW election of members of the dancers [8], the selection of schools [7], and the determination of the best quail eggs [9]. So by applying the method of SAW, is expected to help the election process to place the proper internships and systems can be useful and easy to use for students. 
Although, the fact is many implementations of systems that fail due to not because of technical factors but more on the user factor [10]. Factors influencing people to use the system is intrinsic motivation and extrinsic motivation [11]. Intrinsic motivation in the study was obtained from the perceived ease of use, while the extrinsic motivation derived from perceived usefulness. TAM describe that use of the system will be influenced by usefulness variable and ease of use variable [12].

This research will examine user behavior apprenticeship recommendation system using SAW method based on factors that affected them with the approach of the Technology Acceptance Model (TAM) [12]. The purpose of this research is to know (1) the influence of Perceived Ease of Use (PEOU) against Perceived Usefulness (PU), (2) know the influence of Perceived Ease of Use (PEOU) and Perceived Usefulness (PU) against the Attitude Toward Using (ATU), (3) Knowing the influence Perceived Usefulness (PU) and Attitude Toward Using (ATU) against Behavioral Intention to Use (it), and (4) know how the Behavioral Intention to Use (ITU) against the Actual System Usage (ASU).

\section{Method}

Apprenticeship recommendation system is a system of decision makers who use the method the SAW to help students to determine a suitable place to practice the right internship. Figure 1 shows the use case diagrams on apprenticeship recommendation system.

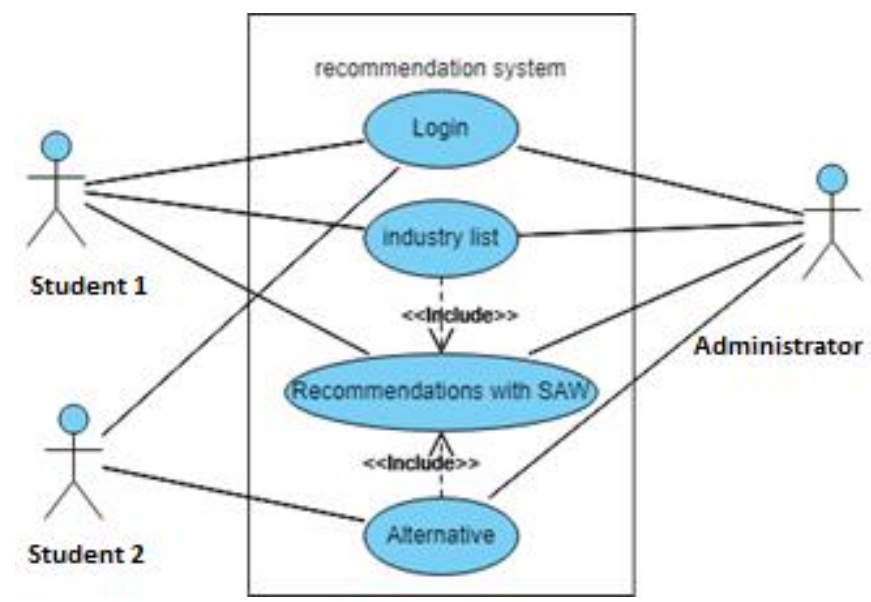

Fig. 1.Use case diagram on apprenticeship recommendation system.

Based on Figure 1, there are three users, namely (1) students who have not registered apprenticeship, (2) students who have registered apprenticeship, and (3) teacher. Before using the system user must log in to get access rights. Students who have not registered apprenticeship can see the list of available industry and may also seek recommendations apprenticeship places. Figure 2 shows the shape Search weighting recommendations place apprenticeships based on the criteria of priority students.

After determining the weighting on each criteria, the system will perform calculations by using the SAW. The results of these calculations are done classification to know the greatest value as the name of industry the most recommended [8], [9], [13]. Figure 3 shows an example of the results of the grant recommendations place of apprenticeship.

Students who have already registered apprenticeship program, at the end of the period of execution of the internship are required to provide an assessment of apprenticeship places. The assessment is used to collect the data and matching each alternative (A) from all of the criteria. Assessment of the internship places form is shown in Figure 4. 


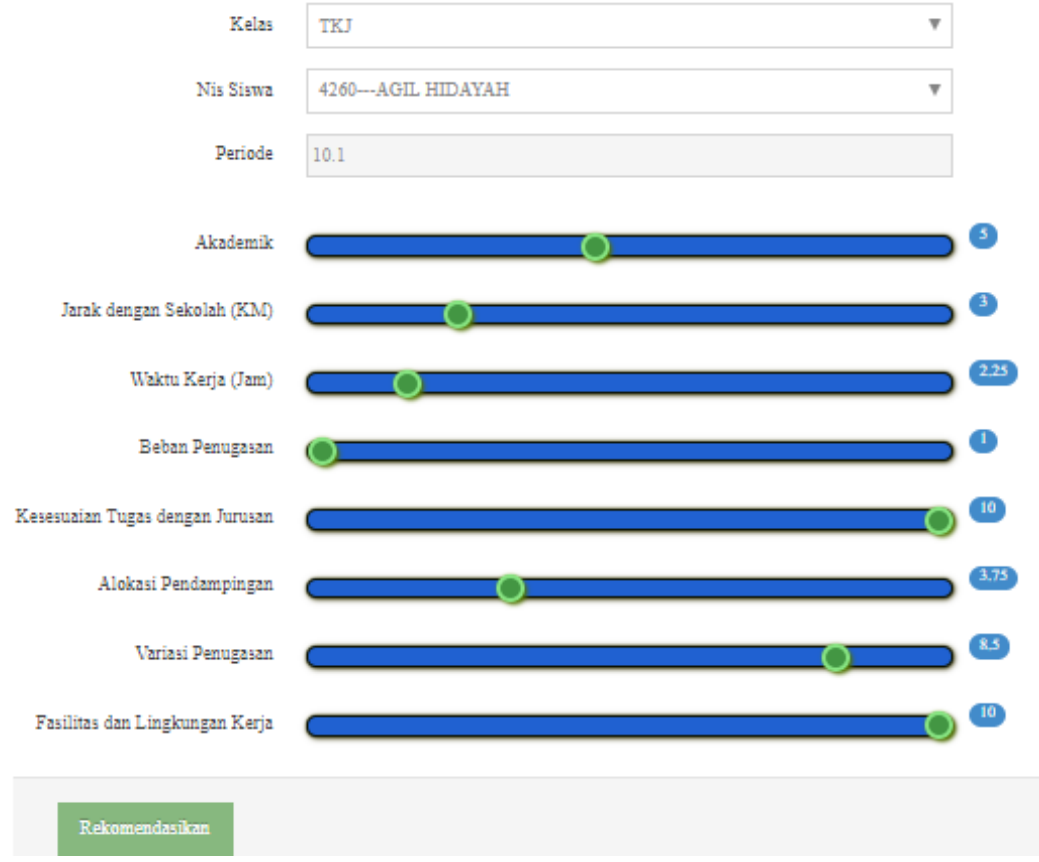

Fig. 2. Weight setting form.

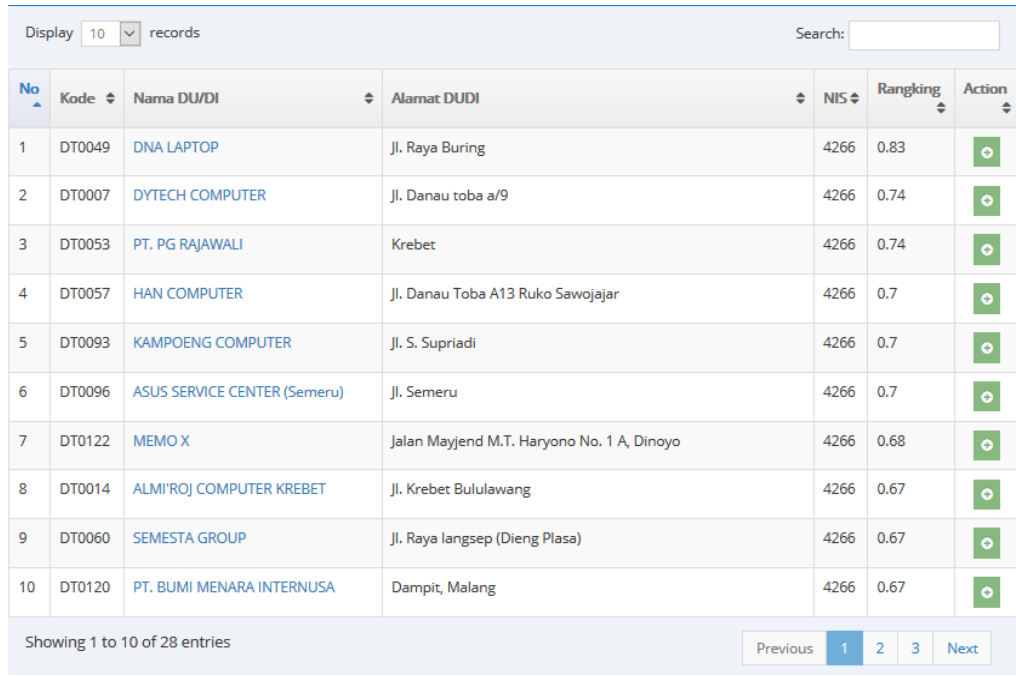

Fig. 3. View of recommendation table.

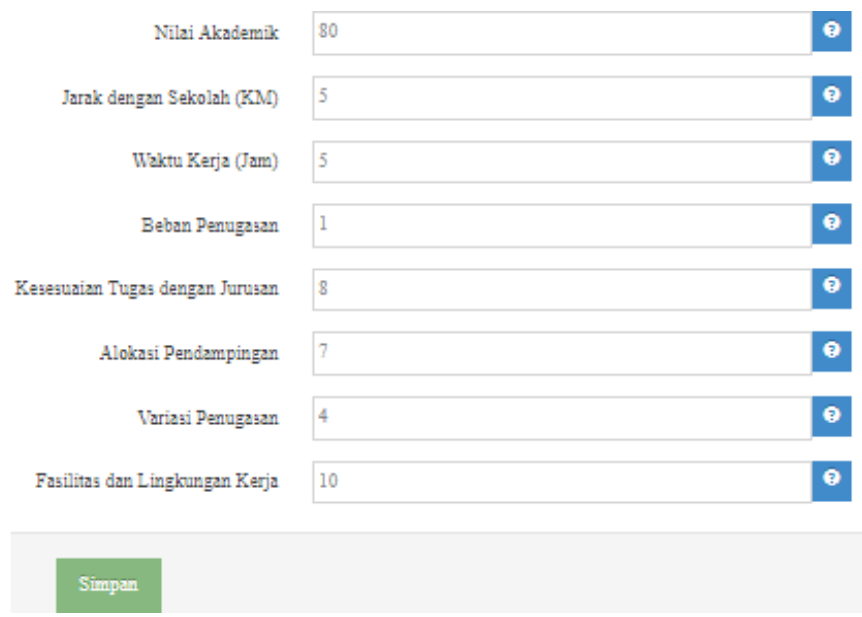

Fig. 4.Internship place assessment. 
In order to be useful in the decision making, the system should be accurate means the information presented must be clear from mistakes and not misleading. Calculation of the accuracy of testing SAW done by comparing the results of the calculations manually through the help of Microsoft Excel with the calculation directly on the system.

User behaviour analysis carried out using instrument data collection approach as TAM combined with linear regression model as an data analysis approach to examine the relationship between the TAM primary variable [10], [14]-[16]. TAM is one model is widely used in understanding acceptance of technology and has been used in many empirical studies [17], [18].

In 1989, TAM was designed by Fred Davis with the aim of making a theoretical framework based on the ' receipt of new technologies [12]. TAM describes the relationship between the user and the technology for predicting user acceptance of technology [19]. Overview the used of TAM prototype can be explained through Figure 5.

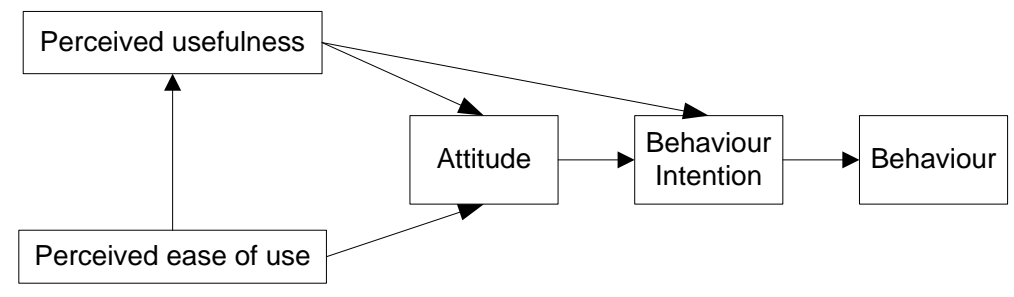

Fig. 5.Framework for the use of TAM [12]

TAM instrument indicators adopted from previous research already done [10], [12]. The instruments used are using Likert scale 4 point (SA) Strongly Agree, (A) Agree, (D) Disagree, and (SD) Strongly Disagree. Analysis of reliability and validity of the instrument used to check and repair the instruments of the TAM was used.

Analysis of the validity of using principal component analysis based on the following criteria: (i) items with loading of 0.50 or more were retained; (ii) items with loading of less than 0.50 were removed; and (iii) items with loading beyond 0.50 on two or more components were removed [15]. Reliability analysis was conducted to know the validity and internal consistency of the instruments using cronbach's alpha [14], [19], [20]. Linear regression analysis was conducted as a tool of analysis and interpretation of data [10], [15], [16].

\section{Result and Discussion}

In terms of data collection, a number of instruments have been 102 TAM with respondents consisted of teachers as much as 1 respondent (1.0\%), admin 2 respondents $(2.0 \%)$, and students as much as 99 respondents $(97.1 \%)$. Characteristics of respondents can be shown detailed demographic data on the Table 1.

Reliability analysis is carried out using the help of IBM SPSS [14]. The test results obtained with the instrument reliability TAM with a cronbach Alpha $(\alpha)$ for 0909 . Since cronbach alpha scores above 0.7 then the instrument can be said as an instrument of measurement is a reliable and instrument stated valid [21] and [22] in [14], [15], [23].

Table 1. Demographic Analysis

\begin{tabular}{ccccc}
\hline Status & Frequency & Percent & Valid Percent & Cumulative Percent \\
\hline Admin & 2 & 2,0 & 2,0 & 2,0 \\
\hline Teacher & 1 & 1,0 & 1,0 & 2,9 \\
\hline Student & 99 & 97,1 & 97,1 & 100,0 \\
\hline Total & 102 & 100,0 & 100,0 & \\
\hline
\end{tabular}

The instruments used on the TAM variables Perceived Usefulness (PU) there are 6 indicators, variable Perceived Ease of Use (PEOU) there are 8 indicators, Attitude Toward Using (ATU) there are 4 indicator variables, Behavioural Intention to Use (ITU) there are 4 indicators, and the Actual System Use (ASU) there are 4 indicators. 
Table 2.

TAM Instrument Result

\begin{tabular}{cccccc}
\hline No & Variable & Respondent & $\mathbf{N}$ & $\begin{array}{c}\text { Total } \\
\text { response }\end{array}$ & $\begin{array}{c}\text { Average } \\
\text { response }\end{array}$ \\
\hline 1 & PU & 102 & 6 & 1997 & 3,26 \\
\hline 2 & PEOU & 102 & 8 & 2600 & 3,19 \\
\hline 3 & ATU & 102 & 4 & 1308 & 3.21 \\
\hline 4 & ITU & 102 & 4 & 1298 & 3,18 \\
\hline 5 & ASU & 102 & 4 & 1188 & 2,91 \\
\hline
\end{tabular}

PU variable on Table 2 was obtained by the respondent's answer amounted to a total of 1997 and an average of 3.26 respondents answers. So it can be concluded that the average user has felt the usefulness of using the system. PEOU variable on Table 2 was obtained by the respondent's answer amounted to a total of 2600 and an average of 3.19 respondents answers. Thus it can be concluded the average users has feel the ease of use of the system. ATU variable in Table 2 gained a total of 1308 respondent answers and the answers of the respondents on average amounted to 3.21. Thus it can be concluded the average user has liked or enjoyed the pleasure of using the system. Variable ITU on Table 2 obtained a total of 1298 respondent's answers and the answers of the respondents on average of 3.18. Thus it can be concluded the average user behaves positively using the system. ASU variable on Table 2 obtained a total of 1188 respondent's answers and the answers of the respondents on average of 2.91. Thus it can be concluded the average user behaves positively related timeliness of system usage.

Furthermore, the magnitude of the influence test performed each variable according to the prototype TAM with regression analysis [10], [14]-[16]. Regression analysis results seen in Table 3.

Table 3. Regression Analysis Result

\begin{tabular}{|c|c|c|c|c|c|c|}
\hline & & \multicolumn{5}{|c|}{ Independent Variable } \\
\hline & & PEOU & $P U$ & $A T U$ & $I T U$ & $A S U$ \\
\hline \multirow{5}{*}{ 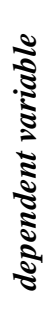 } & PEOU & - & - & - & - & - \\
\hline & PU & $94,4 \%$ & - & - & - & - \\
\hline & ATU & $96,6 \%$ & & - & - & - \\
\hline & ITU & - & \multicolumn{2}{|c|}{$93,6 \%$} & - & - \\
\hline & ASU & - & - & - & $80,9 \%$ & - \\
\hline
\end{tabular}

Based on Table 3, it can be interpreted that the PU variable can be explained by the PEOU variable of $94.4 \%$ while the influence of $5.6 \%$ is caused by other variables outside this model. So that could mean the user perception of ease of system use (PEOU) have a significant influence on the attitude of the users about the usefulness of the system (PU), or in other words there is a significant relationship between variable PEOU against variable PU on the use of the system.

Based on the TAM theory, perceived usefulness is also influenced by perceived ease of use because the easier a system is used, the more useful the system feels. The sense of ease of using technology / information systems will give rise to a feeling in him that the system has uses, and therefore creates a sense of comfort when working with technology / information systems [12], [15], [16].

The ATU variable can be explained by PEOU variables and PU variables by $96.6 \%$ while the influence of $3.6 \%$ is caused by other variables outside this model. So it can be interpreted that the convenience and usability has a significant relationship with the desire to use the system or in other words, the system becomes easier to use and has a high benefit, then the feelings of users to using system is also higher.

The ITU variable can be explained by PU variables and ATU variables by $93.6 \%$ while the influence of $6.4 \%$ is caused by other variables outside this model. So now it can be interpreted that 
the perception of users about the use of usability (PU) and attitude towards users (ATU) have significant influence towards the behavioral intention to use the system (ITU) or in other words the higher perceived benefits of the system will increase the interest of the users to use the system.

Finally, the ASU variable can be explained by the ATU variable by $80.9 \%$ while the influence of $19.1 \%$ is caused by other variables outside this model. So that can be interpreted the higher the interest of someone using the system will increase the actual use of the system in their work.

\section{Conclusion}

Based on the results and discussion, it can be concluded that the SAW method can be used as a solution to assist students in determining the place of internship according to the needs of student. Based on the results of the dissemination of the TAM instrument as an evaluation focusing on the behavior of system users, the average respondent answered enough on each variable. So it can be concluded that the average user has felt the usefulness and ease of use of the system. These TAM variables also have a significant effect. ASU variable is influenced by BIU that is affected by ATU and PU variable. PEOU has an impact on the ATU and PU variable. So any variables will affect the behavior of the user about the actual use of the system.

\section{References}

[1] E. Z. Rutschow and J. Taketa, "An Early Look At The Career Ready Internship Program What Do We Know About Internship Programs, And How Does Cri Compare?," MDRC Build. Knowl. To Improv. Soc. Policy, pp. 2014-2016, 2017.

[2] K. M. Unertl et al., "Next Generation Pathways into Biomedical Informatics : Ten Years of the Vanderbilt Biomedical Informatics Summer Internship Program,” JAMIA Open, vol. 0, no. 0, pp. 1-10, 2018.

[3] Direktorat Pembinaan SMK, Pedoman Praktik Kerja Lapangan. 2017.

[4] T. Lam and L. Ching, "An exploratory study of an internship program: The case of Hong Kong students," Int. J. Hosp. Manag., vol. 26, no. 2, pp. 336-351, 2007.

[5] R. Z. Waryszak, "'Students" expectations from their cooperative education placements in the hospitality industry: an international perspective"," Educ. + Train., vol. 41, no. 1, pp. 33-40, 1999.

[6] B. A. Alyoubi, "Decision Support System and Knowledge-based Strategic Management," Procedia Comput. Sci., vol. 65, no. Iccmit, pp. 278-284, 2015.

[7] Firdausa, A. P. Wibawa, and U. Pujianto, "Model Sistem Pendukung Keputusan Pemilihan Sekolah Menggunakan Metode Saw," Semnasteknomedia Online, vol. 4, no. 1, pp. 3-3-1, 2016.

[8] H. Adela, K. A. Jasmi, B. Basiron, M. Huda, and A. Maseleno, "Selection of dancer member using simple additive weighting," Int. J. Eng. Technol., vol. 7, no. 3, pp. 1096-1107, 2018.

[9] S. Abadi, M. Huda, K. A. Jasmi, S. Shakib, M. Noor, and J. Safar, "Determination of the best quail eggs using simple additive weighting," Int. J. Eng. Technol., vol. 7, no. 2.27, pp. 225-230, 2018.

[10]Y. Iriani, A. Mariana, S. Lestari, and Murnawan, "Analisis Penerimaan Sistem Informasi Berbasis Web Dengan Menggunakan Technology Acceptance Model,” Simp. Nas. RAPI XII, pp. 60-66, 2013.

[11]R. K. Chellappa and P. A. Pavlou, "Perceived information security, financial liability and consumer trust in electronic commerce transactions," Logist. Inf. Manag., vol. 15, no. 5/6, pp. 358-368, 2002.

[12]F. D. Davis, "Perceived Usefulness, Perceived Ease of Use, and User Acceptance of Information Technology," MIS Q., vol. 13, no. 3, pp. 319-340, Sep. 1989.

[13]N. Nurmalini and R. Rahim, "Study Approach of Simple Additive Weighting For Decision Support System,” Int. J. Sci. Res. Sci. Technol., vol. 3, no. 3, pp. 541-544, 2017.

[14]Z. Y. Liu, "An Analysis of Technology Acceptance Model- Exploring user acceptance and intension of taxi-hailing app in Shanghai," An Anal. Technol. Accept. Model, pp. 1-14, 2014.

[15]V. Wilson and U. Mbamba, "Acceptance of Mobile Phone Payments Systems in Tanzania : Technology Acceptance Model Approach,” Bus. Manag. Rev., vol. 2253, pp. 15-25, 2017. 
[16]B. Szajna, "Empirical Evaluation of the Revised Technology Acceptance Model," Manage. Sci., vol. 42, no. 1, pp. 85-92, 1996.

[17]K. a Al-Busaidi and H. Al-Shihi, "A Framework for Evaluating Instructors' Acceptance of Learning Management Systems,” Knowl. Manag. Innov. Adv. Econ. Solut. Vols 1-3, vol. 2010, pp. 1199-1207, 2010.

[18]R. Ramirez-Anormaliza, F. Sabaté, and X. Llinàs-Audet, "The Acceptance And Use Of The E-Learning Systems Among The University Teachers In Ecuador,” EDULEARN16 Proc., pp. 3666-3674, 2016.

[19]H. Holden and R. Rada, "Understanding the influence of perceived usability and technology self-efficacy on teachers' technology acceptance," J. Res. Technol. Educ., vol. 43, no. 4, pp. 343-367, 2011.

[20] S. Y. Park, “An Analysis of the Technology Acceptance Model in Understanding University Students ' Behavioral Intention to Use e-Learning," J. Educ. Technol. Soc., vol. 12, no. 3, pp. 150-162, 2009.

[21]N. M. Suki and N. M. Suki, "Exploring The Relationship Between Perceived Usefulness, Perceived Ease Of Use , Perceived Enjoyment, Attitude And Subscribers ' Intention Towards Using 3G Mobile Services," J. Inf. Technol. Manag., vol. XXII, no. 1, pp. 1-7, 2011.

[22] J. C. Nunnally, Psychometric Theory: 2nd Ed. McGraw-Hill, 1978.

[23] R. H. Shroff, C. C. Deneen, and E. M. W. Ng, "Analysis of the technology acceptance model in examining students ' behavioural intention to use an e- portfolio system," Australas. J. Educ. Technol., vol. 27, no. 4, pp. 600-618, 2011. 